\title{
The Status of the Water Supply and Sanitation Infrastructure in the Kraśnik County
}

\author{
Magdalena Gizińska-Górna ${ }^{1 *}$, Gawron Mariusz,2 \\ 1 Department of Environmental Engineering and Geodesy, University of Life Sciences in Lublin, ul. Akademicka \\ 13, 20-950 Lublin, Poland \\ 2 Students' Scientific Club "Water and Wastewater Management" \\ * Corresponding auhor's e-mail: magdalena.gizinska-gorna@up.lublin.pl
}

\begin{abstract}
The paper describes the status of water supply and sanitation infrastructure in the Kraśnik County. The description is based on the official statistical data and the data obtained in a survey carried out in 2016. The Kraśnik County is located in the Lublin Province and comprises 10 communes: one urban commune (the Municipality of Kraśnik), two urban-rural communes (Annopol and Urzędów), and seven rural communes (Dzierzkowice, Gościeradów, Kraśnik, Szastarka, Trzydnik Duży, Wilkołaz, and Zakrzówek). In 2016, an average of 90.9\% of the County's inhabitants had the access to the mains water, but only $13.5 \%$ were connected to the mains sewerage. The County has six centralized wastewater treatment plants with a total capacity of approximately $14.164 \mathrm{~m}^{3} / \mathrm{d}$. The survey data showed that the records of cesspools were kept in only four of the County's communes: the Municipality of Kraśnik, Urzędów, Wilkołaz, and Zakrzówek. The total number of cesspools in those communes was 4776. The Kraśnik County is in great demand for the construction of on-site domestic wastewater treatment plants, which are an excellent alternative to cesspools. The network of domestic wastewater treatment plants in the Kraśnik County is made up almost entirely of systems with a drainfield, which may pose a serious threat to the soil and water environment. The results of the present study suggest that Commune Offices must take decisive steps to eliminate the existing disproportion between the coverages of the sewerage and water supply systems in the County's communes.
\end{abstract}

Keywords: sanitation infrastructure; commune; water supply system; sewerage system; wastewater treatment plant; cesspool

\section{INTRODUCTION}

Water is an indispensable natural resource, which sustains the life on the Earth and determines the socio-economic development of its various regions. The water resources on the Earth participate in an ever-recurring hydrological cycle that connects the atmosphere, the lithosphere, and the hydrosphere. In Poland, per capita water availability is $1.600 \mathrm{~m}^{3}$ (22nd place in Europe). Because the water reserves of Poland are small, water should be managed rationally and economically, in accordance with the principles of sustainable development [Małecki\&Gołębiak, 2012]. In the EU states, the water and sewerage management and utility infrastructure coverage levels are some of the major foci of the
Community's environmental protection policy [Kłos 2011]. The Poland's accession to the EU has opened the chance for the country to obtain the funds for the expansion of its water supply and sanitation infrastructure [Kocur-Bera 2011]. At the same time, it necessitated harmonization of the Polish legislation on water and wastewater management with that of the EU. As a result, many changes have been made to the law relating to the water supply and sewage disposal methods. One of the main principles set out in the Water Framework Directive 2000/60/EC of 23 October 2000, and Council Directive 91/271/EEC of 21 May 1991 is that the problems related to the supply of drinking water to people as well as the disposal and treatment of wastewater should be handled concurrently. This applies, above all, to 
the rural areas, in which there are still large differences between the water supply and sanitation coverage levels. Although the length of the sewerage network in Poland has doubled in recent years from $84856.2 \mathrm{~km}$ in 2006 to $156780 \mathrm{~km}$ in 2017 [https://bdl.stat.gov.pl], there is still a considerable disproportion between the water supply coverage and sanitation coverage in rural areas [Kłos 2011]. This difference decreased by only $8.3 \%$ in the years $2006-2017$ and currently amounts to about $44.3 \%$ [https://bdl.stat.gov.pl].

Most rural settlements have a dispersed development pattern, which makes the expansion of utility infrastructure problematic. This mainly applies to the sewage disposal systems. According to the National Programme for Municipal Wastewater Treatment (KPOŚK), the construction of a centralized sewerage system is justified when there are at least 120 inhabitants per kilometer of sewerage network: assuming that a single household has four inhabitants, the length of a sewerage network should not exceed $32 \mathrm{~m}$ per household [KPOŚK, 2003]. The maximum length of a sewerage network also depends on the type of residential development: the requirements mentioned above apply to the one-sided development; for the two-sided development, a sewerage network serving about 60 households should not be longer than $2 \mathrm{~km}$. If those thresholds are exceeded, the construction of a decentralized sewerage system with on-site domestic wastewater treatment plants is recommended [Heidrich \&Stańko, 2008; Official Gazette of the Republic of Poland (M.P.) 2017, item 1183].

The studies on the conditions and directions of spatial development, local spatial development plans and commune development strategies determine the directions of growth and spread of settlement, which is preceded by various analyses. When planning the directions of development and expansion of settlements, local governments should take into account the need to provide their inhabitants with basic services, such as the supply of potable water and sanitation. In other words, the directions of development of a settlement largely depend on the ease and legitimacy of the building utility infrastructure in the settlement.

The access to the utility infrastructure significantly influences the spatial organization of the settlement network. In the non-urbanized areas, the access to the utility infrastructure is especially important, because it promotes the non-agricultural economic activity and fosters the multifunctional development of those areas [Kłos 2012].
The aim of the present study was to evaluate the status of the water supply and sanitation infrastructure as well as the need for expanding this infrastructure in the Kraśnik County (powiat kraśnicki), one of the 24 counties of the Lublin Province (województwo lubelskie). The analyses were carried out using the official statistical data and the results of a survey conducted in 2016 in ten communes of the Kraśnik County by the employees of the Department of Environmental Engineering and Geodesy of the University of Life Sciences in Lublin. The survey determined the percentage of the population connected to the mains water supply and sanitation systems, the numbers of cesspools, and the numbers of centralized and off-mains domestic wastewater treatment plants.

\section{METHOD. DESCRIPTION OF THE RESEARCH AREA}

The Kraśnik County is located in the southwestern part of the Lublin Province, in West Roztocze, in the Urzędów Hills. It borders the counties of Opole, Lublin, Janów, Stalowa Wola, Sandomierz, and Opatów. The Kraśnik County is very well communicated as it has access to two national roads, i.e. DK 19 and DK 74 [County Council in Kraśnik 2015]

The County spans over an area of $1005 \mathrm{~km}^{2}$, occupying 5\% of the Lublin Province area. The County's population density is 98 people $\mathrm{km}^{-2}$, which is lower than the average for Poland (123 people $\cdot \mathrm{km}^{-2}$ ), but higher than the average for the Lublin Province ( 85 people $\cdot \mathrm{km}^{-2}$ ). Over $61 \%$ of the County's total population (60 050 people) live in rural areas and 38.8\% live in urban areas (38 132) [County Council in Kraśnik 2015].

The County comprises 10 communes: one urban commune (Municipality of Kraśnik), two urban-rural communes (Annopol and Urzedów), and seven rural communes (Dzierzkowice, Gościeradów, Kraśnik, Szastarka, Trzydnik Duży, Wilkołaz, and Zakrzówek). There are a total of 206 villages in the Kraśnik County. The County's three towns, Kraśnik, Annopol and Urzedów, are inhabited by about $39 \%$ of the County's population. The development potential of those towns is rather limited. The County's settlements have either a nucleated or a dispersed form. A majority of these settlements are nucleated villages with single-family rural residential development. There are also settlements with a dispersed 


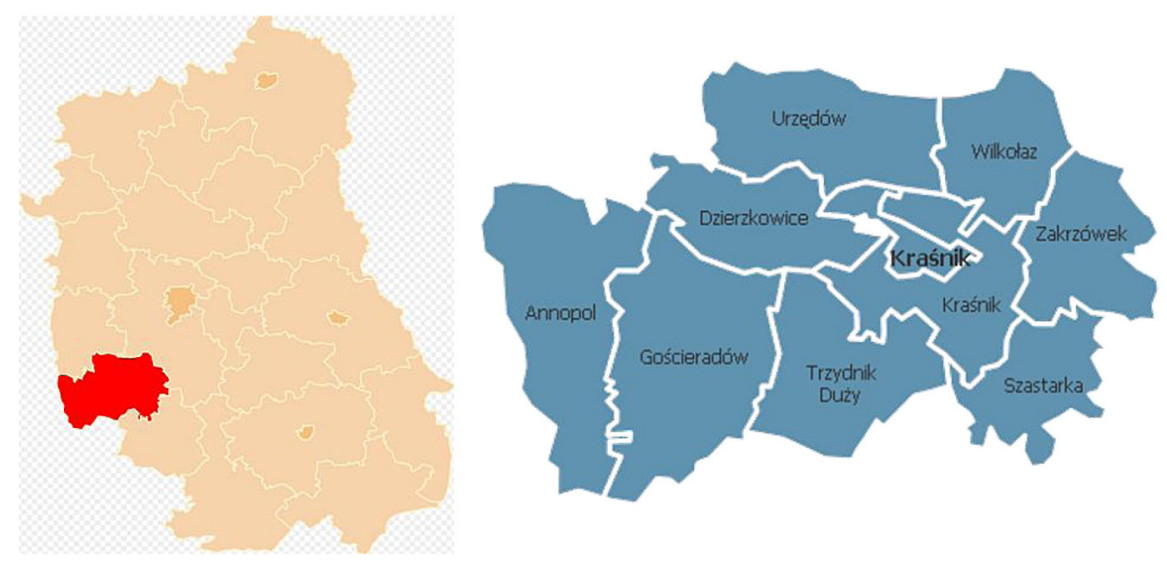

Fig. 1. Map of the Lublin Province featuring Kraśnik County and its communes [www.portalgospodarczy.eurzad.eu]

development pattern and hamlets. The smallest group are the villages with dispersed and irregular development patterns and the villages with concentrations of single farmsteads located outside the main village area.

The Kraśnik County has a very sparse network of surface waters formed by 14 uniform parts of river bodies, six of which have been assessed as poor. The County has extensive areas with no water bodies, especially the south of Kraśnik and Olbięcin. Its surface waters include rivers, unnamed water courses, drainage ditches, and water reservoirs. The Kraśnik County is located in the catchment area of the Baltic Sea, and falls entirely within the Vistula basin. The main rivers are: the Vistula, the Wyżnica with its tributaries, the upper reaches of the Bystrzyca, and the lower reaches of the Sanna. The main watercourse is the river Wyżnica, which runs for $44.22 \mathrm{~km}$ from its source in the vicinity of the Słodków Trzeci village in the Kraśnik commune; it has a catchment area of $508.3 \mathrm{~km}^{2}$ [County Council in Kraśnik 2015].
The main source of water supply in the Kraśnik County are the Cretaceous aquifers. The aquifers are carbonate-silica rock (opoka), marly opoka, marls, and limestones. The depth to the water table varies greatly from place to place. In the top areas, the aeration zone is on average 40 to $50 \mathrm{~m}$ thick, but at some sites, it can be as thick as $70 \mathrm{~m}$. The groundwater from the Cretaceous aquifers is generally of very good quality; it is pure or very pure fresh water which has a natural chemical composition and bacteriological parameters that meet the requirements for potable water. This water can be used for drinking and household purposes without treatment, which means it plays a great role in providing the inhabitants with drinking water.

The soils of the Kraśnik County are good and fair soils, mostly in the third soil-valuation class. The prevailing type of soil are the soils formed from loesses and loess-like formations. The Kraśnik County is a typically agricultural area. Its farms specialize in fruit farming and the

Table 1. Population of the communes of the Kraśnik County in 2014

\begin{tabular}{|l|c|c|}
\hline Administrative unit & Population [people] & Percent of the County's population [\%] \\
\hline Municipality of Kraśnik & 35.508 & 36.2 \\
\hline Commune of Kraśnik & 7.392 & 7.5 \\
\hline Commune of Annopol & 8.929 & 9.1 \\
\hline Commune of Dzierzkowce & 5.379 & 5.5 \\
\hline Commune of Gościeradów & 7.380 & 7.5 \\
\hline Commune of Szastarka & 5.908 & 6.0 \\
\hline Commune of Trzydnik Duży & 6.579 & 6.7 \\
\hline Commune of Urzędów & 8.782 & 8.9 \\
\hline Commune of Wilkołaz & 5.567 & 5.7 \\
\hline Commune of Zakrzówek & 6.758 & 6.9 \\
\hline IN TOTAL: & 98.182 & 100.0 \\
\hline
\end{tabular}


cultivation and production of soft fruits, such as raspberry, strawberry, or currant. Many farms also grow sugar beet (616 farms), rapeseed (417), tobacco, and flax. Hops are also a popular crop (the Lublin Province produces over 90\% of Poland's total hops crop).

Apart from crop production, some farms specialize in animal husbandry. There are cattle, pig, poultry and horse farms in the County [County Council in Kraśnik 2015].

The most important forms of nature conservation in the Kraśnik County include [County Council in Kraśnik 2015]:

- The Kraśnik Protected Landscape Area, which spans $292.74 \mathrm{~km}^{2}$ over the territory of five communes. This conservation area has a very attractive landscape with varied topography. It features the nature areas nearly untransformed by human activity, which provide refuge to wild animals and protected plant species.

- The "Wisła pod Zawichostem" (the Vistula near Zawichost) Nature Reserve. The Reserve is located in the valley of the River Vistula and spans over three provinces: the Lublin Province, the Podkarpacie Province and the Świętokrzyskie Province. It protects breeding, feeding and resting grounds used by rare migratory bird species.

- The "Natalin" Nature Reserve, located in the commune of Urzędów. It provides a safe haven to floral and woodland species. It is one of the smallest woodland nature reserves in Poland as it occupies an area of only 2.52 ha.

- The "Marynopole" Nature Reserve, located in the commune of Gościeradów. It is a woodland reserve with an area of 157 ha. Its main objective is to preserve fir.

- The "Doły Szczeckie"Nature Reserve, also located in the commune of Gościeradów.It is a landscape and woodland reserve with an area of 204 ha. It has many extensive loess gorges.

Apart from nature reserves, the Kraśnik County boasts numerous monuments of animated nature, including trees of various species, which require protection due to their age and size [County Council in Kraśnik 2015]. Because of the richness of its natural environment, the Kraśnik County has a fairly well-developed agritourism, bicycle tourism, heritage tourism and cultural tourism industries.

\section{RESULTS AND DISCUSSION}

The state of the water supply and sanitation infrastructure in the Kraśnik County was determined on the basis of the results of a survey carried out in the Lublin Province in 2016. The survey data included the information on the lengths of the water supply and sewerage networks in the individual communes, the number and capacity of centralized wastewater treatment plants of over $5 \mathrm{~m}^{3} \cdot \mathrm{d}^{-1}$, and the number of the on-site domestic wastewater treatment plants by type of technological design used. In addition, the official statistical data were analyzed.

\section{Water supply and sewerage networks}

The total length of the water supply networks in the Kraśnik County was $1037.3 \mathrm{~km}$. They supplied running water to 88,583 users, i.e. $90.9 \%$ of the County's inhabitants.

Table 2 shows the number of inhabitants with the access to the water supply and sewerage networks and the percent of total connected population for each of the County's communes. Three of those communes:Dzierzkowice, Trzydnik Duży, and Annopol, had full or nearly full water supply coverage. The water supply networks in those communes were $53.7 \mathrm{~km}, 107.1 \mathrm{~km}$, and $153 \mathrm{~km}$ long, respectively. The networks were long enough to supply water to nearly all (99.5\%) inhabitants of the three communes. In those communes, there was a large contrast between the water supply coverage and sanitation coverage. Only $40 \%$ and $29.2 \%$ of the inhabitants were connected to sewers in Dzierzkowice $(28.3 \mathrm{~km})$ and Annopol $(16.8 \mathrm{~km})$, respectively. Trzydnik Duży was the worst case, because it was not connected to sewers at all.

In 2016, the water supply networks in the communes of Wilkołaz and Kraśnik and the Municipality of Kraśnik were approx. $115 \mathrm{~km}$ long, which allowed water to be supplied to $63.8 \%$, $99 \%$, and $95 \%$ of the population of these communes, respectively. Because of the urban character of the municipality of Kraśnik and its nucleated development pattern, the water supply network serviced nearly 32.858 people. The communes of Urzędów and Szastarka had a similar water supply coverage. The water supply networks in those communes were $99.2 \mathrm{~km}$ and $92.2 \mathrm{~km}$ long, respectively, and supplied water to 8.344 inhabitants of the commune of Urzędów 
Table 2. Population connected to water supply and sewerage networks in the Kraśnik County

\begin{tabular}{|l|c|c|c|c|c|}
\hline \multirow{2}{*}{ Commune } & \multirow{2}{*}{ Total population } & \multicolumn{2}{|c|}{ Number of connected inhabitants } & \multicolumn{2}{c|}{$\begin{array}{c}\text { Percent of connected } \\
\text { inhabitants [\%] }\end{array}$} \\
\cline { 3 - 6 } & & $\begin{array}{c}\text { Water supply } \\
\text { network }\end{array}$ & Sewerage network & $\begin{array}{c}\text { Water supply } \\
\text { network }\end{array}$ & Sewerage network \\
\hline $\begin{array}{l}\text { Municipality of } \\
\text { Kraśnik }\end{array}$ & 34.587 & 32.858 & 27.670 & 95 & 80 \\
\hline Kraśnik & 7.426 & 7.338 & 1.824 & 98.8 & 24.6 \\
\hline Annopol & 8.938 & 8.900 & 2.610 & 99.5 & 29.2 \\
\hline Dzierzkowice & 5.500 & 5.500 & 2.200 & 100 & 40 \\
\hline Gościeradów & 7.423 & 3.539 & 651 & 47.7 & 8.8 \\
\hline Szastarka & 6.065 & 5.878 & - & 97 & 0 \\
\hline Trzydnik Duży & 6.560 & 6.560 & - & 100 & 24.7 \\
\hline Urzędów & 8.687 & 8.344 & 2.148 & 96 & 0 \\
\hline Wilkołaz & 5.543 & 3.536 & - & 63.8 & 55 \\
\hline Zakrzówek & 6.742 & 6.130 & 3.707 & 91 & \\
\hline
\end{tabular}

and 6.065 inhabitants of the commune of Szastarka, which represented $96 \%$ and $97 \%$ of their total populations, respectively. The communes with the smallest water supply coverage were Wilkołaz and Gościeradów, each provided water to about 3.500 people, i.e. $64 \%$ and $48 \%$ of their inhabitants, respectively.

In the Kraśnik County, the percent of residential buildings connected to a sanitation network was much smaller than those with the access to a water supply network. The survey showed that there was a very large disproportion between the size of the sanitation system and the water supply system (Fig. 2). In 2016, the total length of the sewerage network in the County was $240.86 \mathrm{~km}$, which constituted only $23.2 \%$ of the length of the water supply network. This length of sewers allowed to collect domestic sewage from an average of $13.5 \%$ of the County's population. The longest sewerage networks were found in the $\mathrm{Mu}$ nicipality of Kraśnik $(73.1 \mathrm{~km})$ and the commune of Zakrzówek $(65.6 \mathrm{~km})$. They collected waste from $80 \%$ and $55 \%$ of the inhabitants of those areas, respectively (Fig. 2). The high coverage of the centralized sanitation system in the municipality of Kraśnik, which was inhabited by over $35 \%$ of the County's population, accounted for a major part of this administrative area's coverage of sewerage services (Table 2). Despite the fact that the communes of Szastarka, Trzydnik Duży and Wilkołaz had a high water supply coverage, they had no centralized sewerage systems. This demonstrates that there were large differences in the coverage between the sewerage and the water supply systems in Kraśnik County. The sewerage networks in the communes of Dzierzkowice, Kraśnik, and Urzędów had similar lengths: $28.3 \mathrm{~km}, 27.2 \mathrm{~km}$, and $23.7 \mathrm{~km}$, respectively. At this level of coverage, the systems allowed collecting sewage from 1,824 inhabitants of the rural commune of Kraśnik (24.6\% of its population), 2,200 inhabitants of the commune

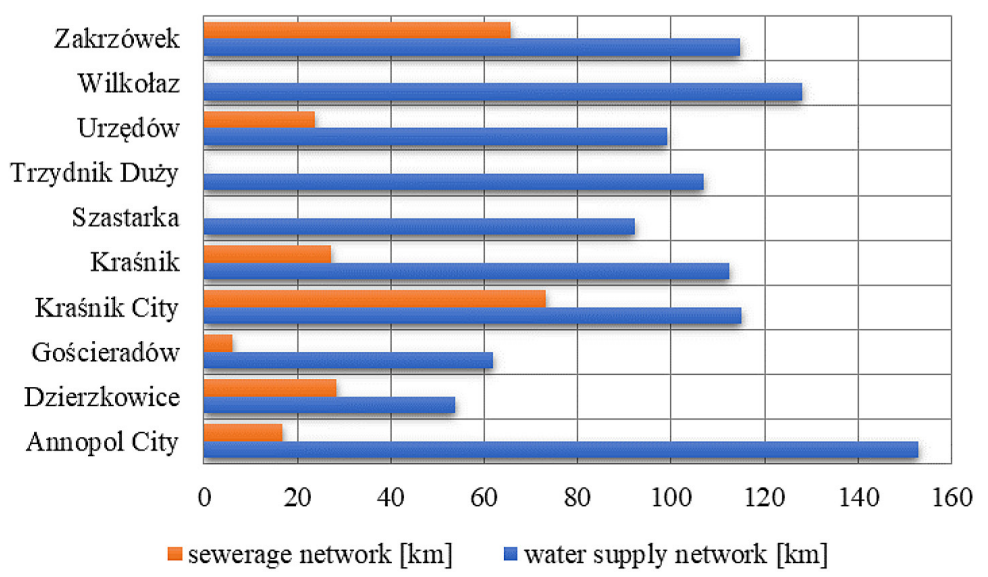

Fig. 2. Lengths of the water supply and sewerage networks in the communes of Kraśnik County 
of Dzierzkowice (40\% of its population) and 2,148 inhabitants of the commune of Urzędów ( $24.7 \%$ of its population). The shortest sewerage networks were those located in the communes of Annopol, $18.8 \mathrm{~km}$, and Gościeradów, $6.2 \mathrm{~km}$. The systems serviced only 2,610 (29.2\%) inhabitants of the Annopol commune and 651 (8.8\%) people living in the commune of Gościeradów. In the commune of Annopol, the sanitation network was disproportionately small compared to the water supply network. In the case of the commune of Gościeradów, the more dispersed development pattern called for larger investments in both the water supply and sanitation infrastructure.

The data in Fig. 2 imply that the water and wastewater management in the Kraśnik County had an adverse effect on the quality of groundwater and surface waters. The graph (Fig. 2) shows that there were huge differences in the coverage between the water supply and the sewerage networks [County Council in Kraśnik 2016]. This disproportion may have been due to various environmental, social, and, above all, economic factors. The water supply systems and sewerage systems, similarly to other utility systems, are characterized by an intricate network structure, high capital intensity, long service life and, related to it, significant differences in the age of the devices used. The disproportion is also caused by the years of disregard for the general and specific principles of sound water management in rural areas, related to the fact that the expansion of the water supply network is viewed as a priority in meeting the needs of the inhabitants of the countryside. In addition, the construction of sewerage systems and wastewater treatment plants is more costly and may be perceived by some members of local communities as an additional financial burden, and not as sound investment in raising the living standards and limiting the environmental degradation. Pursuant to Article 7 of the Act of 8 March 1990 on Gmina Self-Government, provision of water by public utilities and centralized sewage disposal are the responsibility of communes, and the projects in this area are implemented as far as the financial resources of commune self-governments permit. Since the expansion of the utility infrastructure is a particularly costly and time-consuming process, an external support should be provided to the local governments, because neither they nor the rural communities are able to allocate adequate financial resources for this purpose. The local authorities need to look for additional sources of financing of infrastructure investments. What is particularly important is the effective use of external funds, both domestic and foreign. Two programmes in particular - The Sectoral Operational Program "Restructuring and Modernization of the Food Sector and Rural Development", as well as the Integrated Program for the Development of Agriculture - are devoted to the improvement of living conditions in the rural areas and provide funding in support of the expansion and modernization of the utility infrastructure, including the water supply and sewerage systems. In 2008, 2.115 billion PLN was spent on the water supply and sanitation investments in rural areas, and since then, the level of funding for this type of investments has practically remained the same, oscillating around 2 billion PLN [Kłos 2011].

\section{Centralized wastewater treatment plants}

Any centralized sewerage system terminates in a wastewater treatment plant. There are four basic stages of wastewater treatment: mechanical treatment, biological and chemical treatment, biological treatment with the elimination of the nitrogen and phosphorus compounds, and water renewal [Heidrich \& Witkowski 2005].

According to the data collected in the 2016 survey, the Kraśnik County had six centralized wastewater treatment plants at that time. The treatment facilities with the largest capacity were those located in the Municipality of Kraśnik they collected wastewater from the largest number of the County's inhabitants(27.670 people), including the sewage transported from the communes of Wilkołaz, Szastarka and Trzydnik Duży. The municipal wastewater treatment plant in Kraśnik is a mechanical and biological treatment plant with enhanced nutrient removal. In the commune of Gościeradów, there is a mechanicalbiological wastewater treatment plant located in Gościeradów Folwark. It has a capacity of $110 \mathrm{~m}^{3} \cdot \mathrm{d}^{-1}$, and is the County's smallest-capacity plant. The data on the County's centralized wastewater treatment plants are summarized in Table 3.

\section{Cesspools}

Proper wastewater management in rural areas can be problematic, primarily due to the large dispersion of development. In order to provide centralized sanitation services to the rural 
Table 3. Centralized wastewater treatment plants in the Kraśnik County

\begin{tabular}{|l|l|c|}
\hline \multicolumn{1}{|c|}{ Commune } & \multicolumn{1}{|c|}{ Name of treatment plant } & Capacity $\left[\mathrm{m}^{3} \cdot \mathrm{d}^{-1}\right]$ \\
\hline Municipality of Kraśnik & $\begin{array}{l}\text { Municipal Water Supply and Sanitation Company } \\
\text { (KPWiK) in Kraśnik }\end{array}$ & 12.500 \\
\hline Kraśnik & None & - \\
\hline Annopol & Commune Treatment Plant & 600 \\
\hline Dzierzkowice & BIOVAC SBR & 202 \\
\hline Gościeradów & Commune Treatment Plant & 110 \\
\hline Szastarka & None & - \\
\hline Trzydnik Duży & None & 175 \\
\hline Urzędów & Commune Treatment Plant & - \\
\hline Wilkołaz & None & 577 \\
\hline Zakrzówek & Treatment Plant in Bystrzyca & \\
\hline
\end{tabular}

populations, the local governments must invest in the construction of long sewer lines. This entails enormous costs that most communes cannot afford. For this reason, a large number of communes do not build new or expand the existing sewerage networks. Wastewater management in those areas is limited to the on-site infrastructure: cesspools and small domestic wastewater treatment plants. Poland has few well-functioning on-site wastewater disposal systems. The most frequently used type of wastewater receptacle is a cesspool, i.e. a theoretically tight tank, from which sewage is tankered to a wastewater treatment plant. However, when the cesspool is not maintained properly, sewage may leak to the surrounding soil. The maintenance of a cesspool is costly, and the tanks are very often leaky. The contamination of soil and water is one of the main problems associated with the management of domestic wastewater. A leaking cesspool poses a threat not only to its users, but also to their neighbours. This is because wastewater spreads over long distances from the source, carrying pathogenic bacteria that pose a major threat to the environment. By using non-watertight cesspools, people create a closed loop in which the contaminants from these tanks are absorbed by plants, including vegetables and fruits in home gardens, and are ultimately consumed by those who produce them. Cesspools sometimes leak by accident, but much more often, leakage is due to the intentional human activity [Zadroga et al. 2001]. The problem is critical, because the sewage from a leaking cesspool comes into direct contact with people's nearest environment.

The 2016 survey showed that the records of cesspools were only kept in four communes of Kraśnik County: the Municipality of Kraśnik, Urzędów, Wilkołaz and Zakrzówek. In total, around 25.731 people used cesspools in those administrative areas.

The largest number of cesspools were located in the commune of Trzydnik Duży, which had no sewerage system, and so, its entire population used this type of receptacle for the disposal of the domestic wastewater. The exact figures are not known, because no relevant records were kept in this commune. It can only be stated that 6.560 inhabitants of the commune discharged their waste into cesspools. More than 1.000 cesspools each were recorded in the communes of Urzedów (1.405 cesspools), Gościeradów (1.214), and Wilkołaz (1.102). The records kept in Zakrzówek showed that there were 652 operating cesspools in this commune. In total, 4.776 cesspools were registered in the Kraśnik County. Of course, the actual number of those tanks was much higher, but it is impossible to state precisely how much higher it was, because some of the County's communes did not keep a record of them.

\section{On-site domestic wastewater treatment plants}

In the areas with a dispersed development pattern, where the construction of a centralized sewage system is not economically viable, the use of domestic wastewater treatment plants is increasingly recommended as an alternative to cesspools. The fact that the on-site treatment plants are by far cheaper in use than cesspools, is one of the reasons why more and more of them are built every year [Karolinczak et al. 2015]. Domestic wastewater treatment plants can be divided into soil, soil/plant, and packaged systems [Kalenik 2015]. The Polish Standard PN-EN 12566-3:2016-10 [2016] defines a domestic wastewater treatment plant as a facility 
that can serve up to 50 inhabitants. Pursuant to the Water Law Act [2001], the maximum capacity of this type of treatment plant is $5 \mathrm{~m}^{3} / \mathrm{d}$, while the Construction Law [2003] sets the limit at $7.5 \mathrm{~m}^{3} / \mathrm{d}$. Currently, a number of various technological solutions for the treatment of domestic wastewater are used in Poland, such as the systems with a percolation area (a drainfield), sand filters, activated sludge systems, treatment plants with a biological bed, hybrid systems, and constructed wetlands [Jóźwiakowski 2012]. A small domestic wastewater treatment plant should be a two-stage system consisting of a mechanical and a biological stage [Pawęska et al. 2011].

Every facility of this type should comprise a septic tank, as its basic primary-treatment component. A septic tank is used to separate the easilysettling impurities, and prepares sewage for further (biological) treatment.

In the Kraśnik County, the records of domestic wastewater treatment plants were kept in only six out of the ten communes. The survey conducted in 2016 showed that the largest number of domestic wastewater treatment plants were located in the communes of Urzędów (90) and Dzierzkowice (78). The communes of Gościeradów (2) and Zakrzówek (3) had the fewest on-site treatment plants (Fig. 3). In total, there were 206 domestic wastewater treatment plants in the Kraśnik County. This is a very small figure, taking into account the number of cesspools $(4,776)$, which could be replaced by the domestic wastewater treatment plants. The demand for small wastewater treatment systems in the County is very high. However, it is not only the quantity of the systems, but also their effectiveness that matters here. Currently, the domestic wastewater treatment plants use a lot of different treatment technologies. The most commonly used ones are systems with a drainfield, sand filters, constructed wetlands, or systems with biological beds or activated sludge chambers. The hybrid systems that combine the last two solutions are also a popular choice nowadays. According to Błażejewski [2005], the systems consisting of a primary settling tank and a drainfield are the most widely used option (63\%), mainly due to the low costs of installation. However, there is an on-going debate as to whether such systems do indeed effectively remove pollutants or whether they only drain the untreated sewage into the ground [Jucherski \& Walczowski 2001; Paluch \& Pulikowski 2004 ]. In the Kraśnik County, 204 out of the 206 domestic wastewater treatment plants were the systems with a drainfield. Obarska-Pempkowiak [2005] believes that the systems with a percolation area are unacceptable in the long run, because the wastewater discharged from them to receiving water bodies is only treated mechanically. According to Jóźwiakowski et al. [2015], the systems with a drainfield should be banned altogether if the principles of sustainable development are to be genuinely applied.

In recent years, constructed wetlands have been gaining in popularity in Poland and worldwide as the systems for purifying small volumes of water, which ensure a high pollutant removal efficiency [Vymazal 2007]. The only two facilities of this sort in the Kraśnik County were located in the commune of Urzędów. A first was a vertical flow-horizontal flow (VF-HF) system in Skorczyce with a design capacity of $2.5 \mathrm{~m}^{3} \cdot \mathrm{d}^{-1}$. The other facility was located in Popkowice and had a capacity of $4.5 \mathrm{~m}^{3} \cdot \mathrm{d}^{-1}$. A multiple-criteria

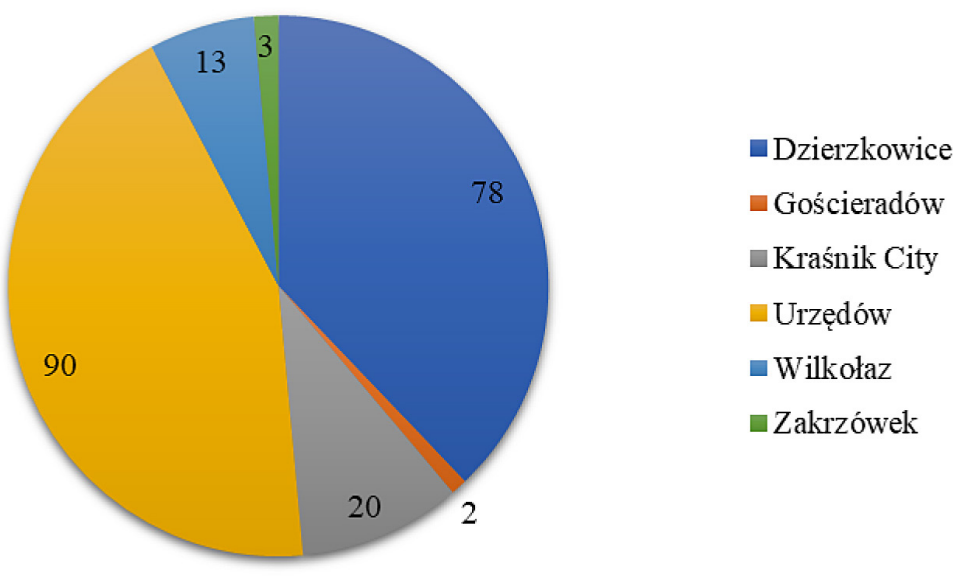

Fig. 3.Number of domestic wastewater treatment plants in the communes of Kraśnik County in 2016 
analysis [Jóźwiakowski et al. 2015] demonstrated that the use of constructed wetlands is in line with the basic principles of sustainable development. The experience to date shows that these systems can be used with great success for many years to treat the domestic sewage in the rural areas [Vymazal 2011; Melián et al. 2010; Dębska et al. 2015; Gajewska et al. 2015; Jóźwiakowski et al. 2015; Gizińska-Górna et al. 2016; Jóźwiakowski et al. 2018; Jucherski et al. 2017; Pawełek\&Bugajski 2017]. In Poland, these systems also begin to be used in the protected areas. The first three constructed wetlands were built in 2014 in the Roztoczański National Park [Jóźwiakowski et al. 2014].

\section{CONCLUSIONS}

1. There was a large disproportion in the coverage between the water supply and sanitation services in the Kraśnik Countycommunes. On average, around $90.9 \%$ of the County's population was connected to running water, but only $13.5 \%$ had access to the mains sewerage, which is a poor result compared to the national average, which was $70 \%$ in 2016 .

2. In the Kraśnik County, the water supply network was being expanded at a much faster pace than the sewerage network. Two of the County's communes, Trzydnik Duży and Dzierzkowice, had full water supply coverage $(100 \%$ of the population had access to running water), which is in stark contrast to the fact that the former had no sewerage system and the latter provided the sewerage services to only $40 \%$ of its inhabitants.

3. The commune with the highest sanitation coverage level was the municipality of Kraśnik. It had $27,670 \mathrm{~km}$ of sewers, which collected wastewater from $80 \%$ of the municipality's residents. In the remaining communes of the County, the percentage of population connected to and serviced by a sewerage system was below $40 \%$.

4. The County had six centralized wastewater treatment plants with a total capacity of approximately $14,164 \mathrm{~m}^{3} / \mathrm{d}$.

5. The survey data showed that records of cesspools were kept in only four of the County's communes: the Municipality of Kraśnik, Urzędów, Wilkołaz, and Zakrzówek. In total, there were 4,776 cesspools in that area.
6. The network of domestic wastewater treatment plants in the Kraśnik County was made up almost entirely of systems with a drainfield, which may pose a serious threat to the soil and water environment.

7. The commune of Urzędów boasted the County's only two constructed wetlands, which provided a very high pollutant removal efficiency.

8. Local governments should strive to increase the coverage of their sewage networks, maintain their water supply networks in good condition, and assist users in replacing cesspools with domestic wastewater treatment plants in the areas where the latter do not pose a threat to the groundwater.

Publication is funded by the Polish National Agency for Academic Exchange under the International Academic Partnerships Programme from the project „Organization of the 9th International Scientific and Technical Conference entitled Environmental Engineering, Photogrammetry, Geoinformatics - Modern Technologies and Development Perspectives".

\section{REFERENCES}

1. Błażejewski R. 2005. Aktualny status przydomowych oczyszczalni ścieków i perspektywy ich rozwoju. Wodociągi - Kanalizacja 1/2005.

2. Construction Law Act of 27 March 2003 [Journal of Laws no. 80/03, item 718, art. 29 para. 1, point. 3] (in Polish).

3. Dębska A., Jóźwiakowski K., Gizińska-Górna M., Pytka A., Marzec M., Sosnowska B., Pieńko A. 2015. The efficiency of pollution removal from domestic wastewater in constructed wetland systems with vertical flow with Common reed and Glyceria maxima. Journal of Ecological Engineering 16 (5) 110-118.

4. Gajewska M., Jóźwiakowski K., Ghrabi A., Masi F. 2015. Impact of influent wastewater quality on nitrogen removal rates in multistage treatment wetlands. Environ. Sci. Pollut. Res. 22, 12840-1284.

5. Gizińska-Górna M., Czekała W., Jóźwiakowski K., Lewicki A., Dach J., Marzec M., Pytka A., Janczak D., Kowalczyk-Juśko A., Listosz A. 2016. The possibility of using plants from hybrid constructed wetland wastewater treatment plants for energy purposes. Ecological Engineering 95, 534-541.

6. Heidrich Z., Stańko G. 2008. Kierunki rozwiązań oczyszczalni ścieków dla wiejskich jednostek osadniczych. Infrastruktura i Ekologia Terenów Wiejskich, 5, pp. 169-177. 
7. Heidrich Z., Witkowski A. 2005. Urządzenia do oczyszczania ścieków. Projektowanie, przykłady obliczeń - 2nd edition. Wyd. Seidel-Przywecki. Warsaw: https://bdl.stat.gov.pl/BDL/dane/teryt/ kategoria/17

8. Jóźwiakowski K. 2012. Przydomowe oczyszczalnie ścieków na terenach wiejskich - cz. I. Inżynier Budownictwa, 99, pp. 57-60.

9. Jóźwiakowski K., Bugajski P., Kurek K., Nunes de Carvalho M. F, Araújo Almeida M. A., Siwiec T., Borowski G., Czekała W, Dach J, Gajewska M. 2018. The efficiency and technological reliability of biogenic compounds removal during long-term operation of a one-stage subsurface horizontal flow constructed wetland. Separation and Purification Technology 202, 216-226.

10. Jóźwiakowski K., Marzec M., Słowik T., KowalczykJuśko A., Gizińska M., Pytka A., Skwarzyńska A., Gajewska M., Steszuk A. Grabowski T., Szawara Z. 2014. The concept of construction of hybrid constructed wetland for wastewater treatment in Roztoczański National Park. The Regional Barometer 14 (4), 91-102.

11. Jóźwiakowski K., Mucha Z, Generowicz A., Baran S., Bielińska J., Wójcik W. 2015. The use of multi-criteria analysis for selection of technology for a household WWTP compatible with sustainable development. Archives of Environmental Protection $3 / 2015$.

12. Jucherski A, Nastawny M., Walczowski A., Jóźwiakowski K., Gajewska M. 2017. Assessment of the technological reliability of a hybrid constructed wetland for wastewater treatment in a mountain eco-tourist farm in Poland. Water Sci. Technol. 75 (11), 2649-2658.

13. Jucherski A, Walczowski A. 2001. Drenaże rozsączające. Oczyszczanie czy odprowadzanie nieoczyszczonych ścieków do gleby. Wiadomości Melioracyjne i Łąkarskie No. 3 (390), 131-132.

14. Kalenik M. 2015. Zaopatrzenie w wodę i odprowadzanie ścieków. Second revised edition. Wyd. SGGW. Warszawa.

15. Karolinczak B., Miłaszewski R., Sztuk A. 2015. Cost-effectiveness analysis of different techno $\neg$ logical variants of single-house sewage treatment plants. Rocznik Ochrona Środowiska, 17, 726-746 (in Polish).

16. Kłos L. 2011. Stan infrastruktury wodno-kanalizacyjnej na obszarach wiejskich w Polsce a wymogi ramowej dyrektywy wodnej. Studia i prace wydziału nauk ekonomicznych i zarządzania, no. 24, Szczecin.

17. Kłos L. 2012. Wpływ infrastruktury technicznej na atrakcyjność obszarów wiejskich. Studia i prace wydziału nauk ekonomicznych i zarządzania, no. 25, Szczecin.

18. Kocur-Bera K. 2011. Rozwój infrastruktury na przykładzie wybranych gmin wiejskich. Infrastruktura i Ekologia Terenów Wiejskich, 1, pp. 29-37.

19. Małecki Z. J., Gołębiak P. 2012. Zasoby wodne Polski i Świata. Zeszyty naukowe - Inżynieria lądowa i wodna w kształtowaniu środowiska. No. 7. pp. $50-52$

20. Melián J.A. H., Rodríguez A. J. M., Araña J., Díaz O. G., Henríquez J. J. G. 2010, Hybrid constructed wetlands for wastewater treatment and reuse in the Canary Islands. Ecol. Eng. 36, 891-899.

21. Obarska-Pempkowiak H. 2005. Oczyszczalnie hydrofitowe w świetle przepisów UE. Zeszyty Naukowe Wydziału Budownictwa i Inżynierii Środowiska Politechniki Koszalińskiej no. 22, 77-97.

22. Paluch J., Pulikowski K. 2004. Wybrane problemy związane $\mathrm{z}$ budową zagrodowych oczyszczalni ścieków z drenażem rozsączającym. Wiad. Mel. i Łąk., z. 4, 191-198.

23. Pawełek J., Bugajski P. 2017. The development of household wastewater treatment plants in Poland - advantages and disadvantages. Acta Scientiarum Polonorum, Formatio Circumiectus, 16(2), 3-14 (in Polish).

24. Pawęska K., Pulikowski K., Strzelczyk M., Rajmund A. 2011. Septic tank - basic element of household treatment plant. Infrastruktura i Ekologia Terenów Wiejskich, 10, 43-53 (in Polish).

25. Polish Standard PN-EN 12566-3:2016-10. 2016. Small wastewater treatment systems for up to 50 PT - Part 3: Packaged and / or site assembled domestic sewage treatment plants (in Polish).

26. County Council in Kraśnik 2015. Development Strategy for Kraśnik County for the years 20162022 with projections up to 2025 (in Polish).

27. Act of 8 March 1990 on Commune Self-government, Journal of Laws of 2001, no. 42, item 1591, with later amendments.

28. Vymazal J. 2007, Removal of nutrients in various types of constructed wetlands. Sci. Tot. Environ. 380, 48-65.

29. Vymazal J. 2011, Constructed wetlands for wastewater treatment: Five decades of experience. Environ. Sci. Technol. 45, 61-69.

30. Water Law Act of 18 July 2001, [Journal of Laws no. 115/01, item 1229, art. 36, 39, 42] (in Polish). www.portalgospodarczy.eurzad.eu

31. Zadroga B., Olańczuk-Neyman K., 2001. Ochrona i rekultywacja pod-łoża gruntowego. Gdańsk: Wydawnictwo PGdań, pp. 226. 